\title{
EXPERIMENTAL POTASSIUM DEPLETION IN NORMAL HUMAN \\ SUBJECTS. II. RENAL AND HORMONAL FACTORS IN \\ THE DEVELOPMENT OF EXTRACELLULAR ALKALOSIS DURING DEPLETION*
}

\author{
By E. J. HUTH, R. D. SQUIRES AND J. R ELKINTON $\dagger$
}

(From the Chemical Section of the Department of Medicine and the Department of Physiology, University of Pennsylvania, School of Medicine, Philadelphia, Pa.)

(Submitted for publication June 3, 1958; accepted February 19, 1959)

In the preceding paper (1) experimental depletion of potassium in normal human subjects did not produce an extracellular metabolic alkalosis of the severity which usually occurs in patients with comparable potassium deficits. Much investigative study has been applied to this association but, because of the many factors involved in such patients, the relative importance of such factors in the etiology of this association in man remains unclear.

Most of our knowledge of the metabolic derangements induced in mammals by potassium depletion has come from studies in rats (212). The depletion in rats is usually accompanied by metabolic alkalosis of varying severity. A hypothesis accounting for the alkalosis has been formulated by Darrow, Cooke and coworkers (2-4) and has been given additional support by the studies of Orloff, Kennedy and Berliner (9). In brief, the loss of potassium from cells is replaced in part by hydrogen ion from extracellular fluid, the latter shift resulting in an intracellular acidosis and an extracellular alkalosis. This primary cellular distortion of acid-base equilibrium is then maintained by the kidney by an enhancement of tubular reabsorption of bicarbonate over that of chloride and the excretion of a relatively acid urine. In these rat studies the absence or presence and degree of alkalosis appear to be related to many variables including the duration and severity of the depletion, the protein content of the diet, the acidbase composition of the diet and the use of desoxycorticosterone in promoting depletion.

* This study was supported by the United States Public Health Service (Grant H-340) and the C. Mahlon Kline Fund of the Department of Medicine, University of Pennsylvania.

$\dagger$ Established Investigator of the American Heart Association.
Evidence has been reported that this phenomenon can be induced experimentally in man (13, 14). But potassium depletion in man does not always result in an unequivocal extracellular alkalosis either experimentally (1) or clinically (15), and Moore and co-workers (16) have shown that loss of acid as gastric fluid and interference by adrenocortical hormones with renal compensations for internal exchanges may be at least as important in causing a manifest alkalosis.

The experiments in this paper were devised to provoke in normal man the appearance of extracellular metabolic alkalosis in conjunction with potassium depletion, without and with concomitant administration of desoxycorticosterone, and without variation of the anion-cation balance of the intake high in sodium or loss of chloride in gastric fluid. The analysis of the results has been aimed at examining the validity of the Darrow hypothesis for man. The derived data confirm an internal shift of hydrogen from extracellular fluid and show little alteration of extracellular acid-base equilibrium by changes in the renal excretion of acid, which changes appear to influence primarily the intracellular content of acid.

\section{EXPERIMENTAL PROCEDURE AND METHODS}

Human subjects and design of study. Four metabolic balance studies were done on three volunteer medical students in good health. They gave no history of any past illness that might affect the studies. The basic study design was that of a five day control period followed by a potassium depletion period of 12 to 16 days. The potassium depletion period proceeded for seven to 10 days and then desoxycorticosterone acetate (DCA) $(20 \mathrm{mg}$. per day in oil given intramuscularly) was added to the program for five to six days. In all the studies, chloride $\left(\mathrm{Cl}^{-}\right)$and bicarbonate $\left(\mathrm{HCO}_{3}^{-}\right)$were consumed in a ratio of $3: 1$; one subject, J. M.1, received $129 \mathrm{mEq}$. of sodium per day throughout, the other subjects received $348 \mathrm{mEq}$. per day. 
During depletion, the potassium intake averaged about $1 \mathrm{mEq}$. per day.

The specific studies were designed as follows: The control period for each subject was five days; the depletion period was seven days for J. M.2, eight days for $J . M_{\cdot 1}$ and
R. H., and 10 days for J. S.; the succeeding period of depletion plus DCA was five days for J. M.1 and J. M.2, and six days for R. H. and J. S. ; in addition R. H. was further depleted after DCA for two days and then repleted for two days.

TABLE I

Venous serum and arterialized cutaneous blood values

\begin{tabular}{|c|c|c|c|c|c|c|c|c|c|c|c|}
\hline \multirow[b]{2}{*}{ Subject } & \multirow[b]{2}{*}{ Day } & \multicolumn{4}{|c|}{ Venous serum } & \multicolumn{6}{|c|}{ Arterialized cutaneous blood } \\
\hline & & $\mathbf{K}$ & $\mathrm{Na}$ & $\mathrm{Cl}$ & $\mathrm{CO}_{2}$ & $\mathrm{pH}$ & $\mathrm{CO}_{2}$ & $\mathrm{pCO}_{2}$ & B B* & Hct. & $\mathrm{Hb}$. \\
\hline & & $m E q . / L$ & $m E q . / L$ & $m E q . / L$ & $m M o l e s / L$ & & mMoles/L. & $m m . ~ H g$ & $m E q . / L$ & $\%$ & mMoles/L \\
\hline & $\begin{array}{l}3 \\
5\end{array}$ & 4.0 & 138 & 104 & 28.7 & 7.43 & 22.8 & 41 & 50 & 44 & 9.6 \\
\hline \multicolumn{12}{|c|}{ Depletion } \\
\hline & $\begin{array}{l}1 \\
2 \\
3 \\
4 \\
5 \\
6 \\
7 \\
8\end{array}$ & $\begin{array}{l}4.0 \\
4.0 \\
3.8 \\
3.7 \\
3.8 \\
3.7 \\
3.8 \\
3.3\end{array}$ & $\begin{array}{l}138 \\
137 \\
138 \\
137 \\
138 \\
138 \\
138 \\
138\end{array}$ & $\begin{array}{l}110 \\
105 \\
107 \\
105 \\
108 \\
107 \\
104 \\
104\end{array}$ & $\begin{array}{l}27.4 \\
26.4 \\
27.1 \\
27.5 \\
24.6 \\
28.3 \\
28.2 \\
28.0\end{array}$ & 7.44 & 23.3 & 40 & 50 & 40 & 8.6 \\
\hline \multicolumn{12}{|c|}{ Depletion + DCA } \\
\hline & $\begin{array}{r}9 \\
10 \\
11 \\
12 \\
13\end{array}$ & $\begin{array}{l}3.9 \\
3.3 \\
3.3 \\
3.1\end{array}$ & $\begin{array}{l}138 \\
138 \\
138 \\
\\
138\end{array}$ & $\begin{array}{r}101 \\
103 \\
103 \\
94\end{array}$ & $\begin{array}{l}29.1 \\
31.1 \\
28.7 \\
29.3\end{array}$ & $\begin{array}{l}7.41 \\
7.38 \\
7.41 \\
7.43 \\
7.38\end{array}$ & $\begin{array}{l}22.5 \\
23.2 \\
22.4 \\
22.9 \\
23.1\end{array}$ & $\begin{array}{l}41 \\
45 \\
41 \\
40 \\
45\end{array}$ & $\begin{array}{l}48 \\
48 \\
48 \\
49 \\
48\end{array}$ & $\begin{array}{l}43 \\
42 \\
40 \\
40 \\
39\end{array}$ & $\begin{array}{l}8.6 \\
8.2 \\
8.4 \\
8.4 \\
8.1\end{array}$ \\
\hline \multicolumn{12}{|c|}{ High $\mathrm{Na}^{+}$intake } \\
\hline 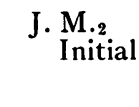 & 5 & 4.0 & 141 & 105 & 24.5 & 7.39 & 20.7 & 40 & 47 & 44 & 8.7 \\
\hline \multicolumn{12}{|c|}{ Depletion } \\
\hline & $\begin{array}{l}1 \\
2 \\
3 \\
4 \\
5 \\
6 \\
7\end{array}$ & $\begin{array}{l}4.0 \\
3.8 \\
3.5 \\
3.5 \\
3.6 \\
3.5 \\
3.5\end{array}$ & $\begin{array}{l}140 \\
140 \\
141 \\
140 \\
140 \\
140 \\
141\end{array}$ & $\begin{array}{l}105 \\
105 \\
106 \\
108 \\
107 \\
107 \\
107\end{array}$ & $\begin{array}{l}26.0 \\
26.0 \\
24.7 \\
25.3 \\
24.8 \\
25.7 \\
26.4\end{array}$ & $\begin{array}{r}7.39 \\
7.39 \\
7.42 \\
7.42\end{array}$ & $\begin{array}{l}20.8 \\
20.1 \\
21.0 \\
21.6\end{array}$ & $\begin{array}{l}40 \\
40 \\
38 \\
39\end{array}$ & $\begin{array}{l}47 \\
46 \\
47 \\
48\end{array}$ & $\begin{array}{l}45 \\
46 \\
40 \\
40\end{array}$ & $\begin{array}{l}8.5 \\
9.0 \\
\\
8.5 \\
8.2\end{array}$ \\
\hline \multicolumn{12}{|c|}{ Depletion + DCA } \\
\hline . & $\begin{array}{r}8 \\
9 \\
10 \\
11 \\
12\end{array}$ & $\begin{array}{l}3.3 \\
3.1 \\
2.8 \\
2.8 \\
2.7\end{array}$ & $\begin{array}{l}140 \\
140 \\
143 \\
143 \\
143\end{array}$ & $\begin{array}{l}106 \\
106 \\
106 \\
106 \\
106\end{array}$ & $\begin{array}{l}27.1 \\
27.8 \\
25.8 \\
27.9 \\
28.1\end{array}$ & $\begin{array}{l}7.44 \\
7.46 \\
7.43 \\
\\
7.45\end{array}$ & $\begin{array}{l}22.6 \\
23.5 \\
22.4 \\
22.8 \\
22.1\end{array}$ & $\begin{array}{l}39 \\
39 \\
39 \\
\\
36\end{array}$ & $\begin{array}{l}49 \\
50 \\
50 \\
48\end{array}$ & $\begin{array}{l}39 \\
37 \\
41 \\
37 \\
35\end{array}$ & $\begin{array}{l}7.9 \\
8.0 \\
8.1 \\
7.5\end{array}$ \\
\hline \multicolumn{11}{|l|}{ R. H. } & 9.5 \\
\hline \multicolumn{12}{|c|}{ Depletion } \\
\hline & $\begin{array}{l}1 \\
2 \\
3 \\
4 \\
5 \\
6 \\
7 \\
8\end{array}$ & $\begin{array}{l}4.0 \\
3.9 \\
3.6 \\
3.5 \\
3.5 \\
3.7 \\
3.5 \\
3.4\end{array}$ & $\begin{array}{l}145 \\
144 \\
144 \\
143 \\
145 \\
148 \\
147 \\
145\end{array}$ & $\begin{array}{l}103 \\
104 \\
105 \\
106 \\
107 \\
106 \\
105 \\
106\end{array}$ & $\begin{array}{l}30.0 \\
28.0 \\
26.9 \\
28.2 \\
29.4 \\
27.6 \\
28.4 \\
29.1\end{array}$ & $\begin{array}{l}7.43 \\
7.44 \\
7.46 \\
7.42 \\
7.43\end{array}$ & $\begin{array}{l}21.8 \\
21.8 \\
22.4 \\
21.2 \\
22.7\end{array}$ & $\begin{array}{l}40 \\
39 \\
39 \\
40 \\
41\end{array}$ & $\begin{array}{l}50 \\
50 \\
\\
51 \\
49 \\
51\end{array}$ & $\begin{array}{l}48 \\
46 \\
48 \\
47 \\
46\end{array}$ & $\begin{array}{l}9.4 \\
9.1 \\
9.3 \\
9.1 \\
9.0\end{array}$ \\
\hline
\end{tabular}


TABLE I-Continued

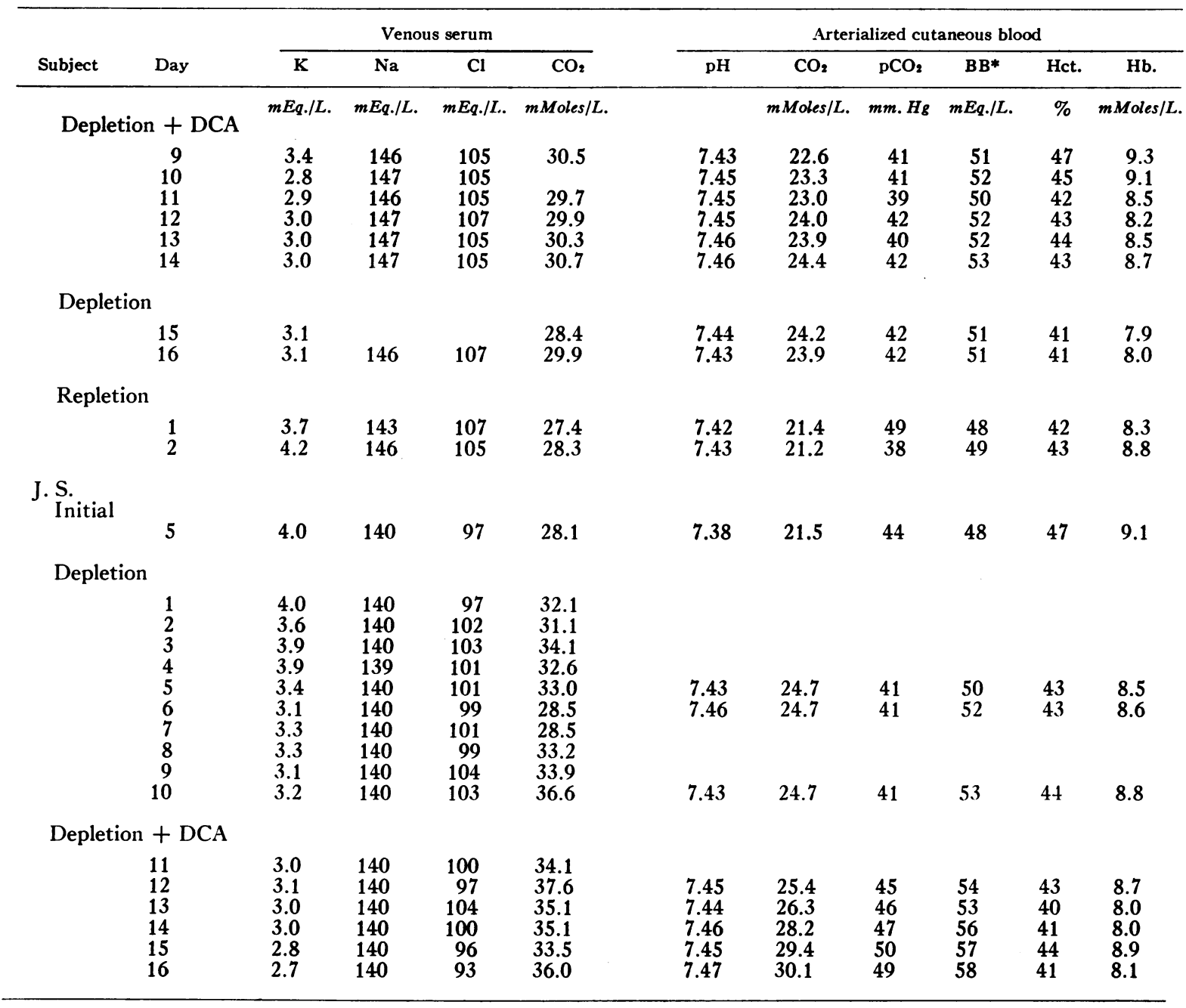

* Buffer base.

The subjects slept, took meals and gave metabolic specimens on the Metabolic Unit. They were allowed normal daytime activities; during studies in warm months, subjects were confined largely to the Metabolic Unit or airconditioned parts of the hospital. Specimens were collected as in the previous study (1).

Diets. The subjects ingested prepared milk and vitamin supplements. The milk was rendered practically free of monovalent ions by repeated passage through mono-bed cation and anion ion exchange resins. ${ }^{1}$ These resins yield hydroxyl ion for monovalent anions and hydrogen ion for cations. The milk was then reconstituted with weighed portions of sodium and potassium chloride and bicarbonate as required by the study plan. The amount of milk ingested each day was held constant; the protein and caloric intake approximated normal levels. No additional water was drunk by the subjects. Milk was treated, as described

${ }^{1}$ Amberlite MB-3, Rohm and Haas, Philadelphia, Pa. above, every two days, and an aliquot from each lot was analyzed for sodium, potassium, chloride, nitrogen and solids content. Several aliquots were analyzed for calcium and phosphorus and were found to contain about twothirds of the amounts in normal milk.

Chemical methods and calculations. The milk and metabolic specimens (urine, stool and blood) were analyzed by the chemical methods presented in the preceding paper (1). Metabolic calculations were carried out as described in detail elsewhere (17) and as summarized in part below.

RESULTS : OBSERVED

The data are presented in Tables I to III and in Figures 1 to 7 .

\section{Blood and serum changes}

The major changes found were in the serum potassium level and in the indicators of acid-base equilibrium (Table I, Figure 1). 

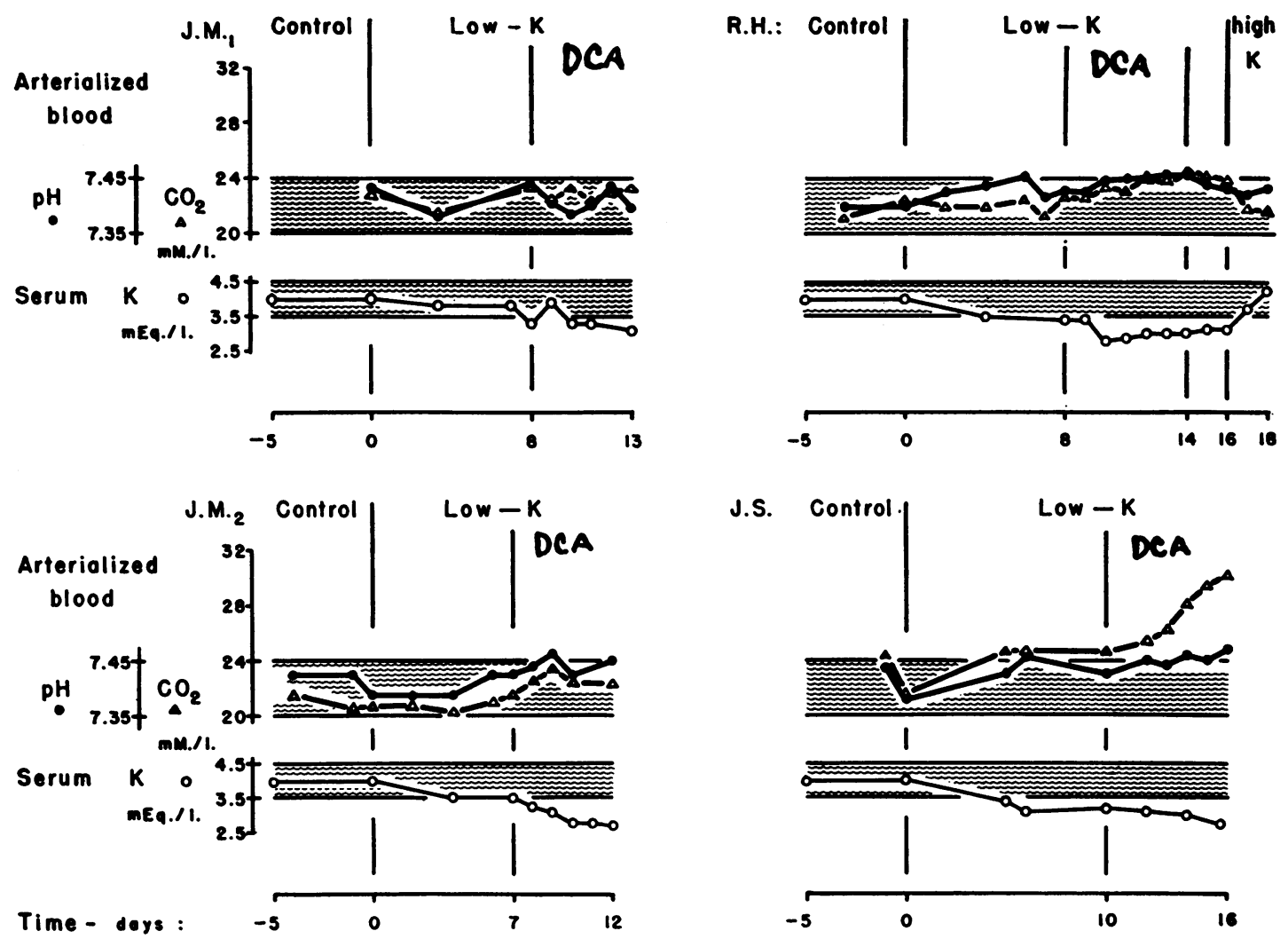

Fig 1. Total $\mathrm{CO}_{2}$ Content and $\mathrm{PH}$ of Arterial Blood and Venous Serum Concentration of Potassium During Potassium Deprivation and Administration of Desoxycorticosterone

Serum potassium concentration fell below normal in all four subjects. The arterial $\mathrm{CO}_{2}$ tended to rise slightly in two and only rose definitely to alkalotic levels in one of the four subjects.

All of the subjects started the depletion period with serum potassium concentrations of $4.0 \mathrm{mEq}$. per L. As depletion progressed, the concentrations fell progressively with the greatest decline being to $2.7 \mathrm{mEq}$. per $\mathrm{L}$. in 12 days and the smallest to $3.1 \mathrm{mEq}$. per L. in 13 days.

During depletion, acid-base variables changed at some time in the three subjects on a high sodium intake in the direction of metabolic alkalosis when compared with the final values of the predepletion period. For the venous serum $\mathrm{CO}_{2}$ content, the maximum rises ranged from +0.4 to +9.5 mMoles per $\mathrm{L}$. The maximum rises in cutaneous arterialized whole blood variables ranged as follows: $\mathrm{CO}_{2}$ content, +0.5 to +8.6 mMoles per L.; $\mathrm{pH},+0.01$ to +0.09 units; and buffer base, 0 to $+10 \mathrm{mEq}$. per L. The largest changes took place during the period of DCA administration. Respiratory compensation was fairly good as shown by a rise in calculated $\mathrm{pCO}_{2}$ and by a maximum $\mathrm{pH}$ of 7.47 .

\section{External balances}

Urine potassium declined rapidly to an average output on the seventh day of depletion of 12 mEq. in the subjects on high sodium intakes (J. M.2, R. H. and J.S.) and to $7 \mathrm{mEq}$. in the subject on normal sodium intake (J. M.1) (Table II). Stool content of potassium also decreased during depletion.

DCA raised urinary potassium to daily maxima of nine to $25 \mathrm{mEq}$. above the output of the last day of depletion without DCA. The stool content of potassium increased similarly to a lesser degree.

The total negative balance of potassium attained by the end of the depletion, 12 to 16 days (including the DCA period), ranged from -288 to $-618 \mathrm{mEq}$. $(-221$ to $-502 \mathrm{mEa}$. when 
TABLE II

Urine and stool analyses

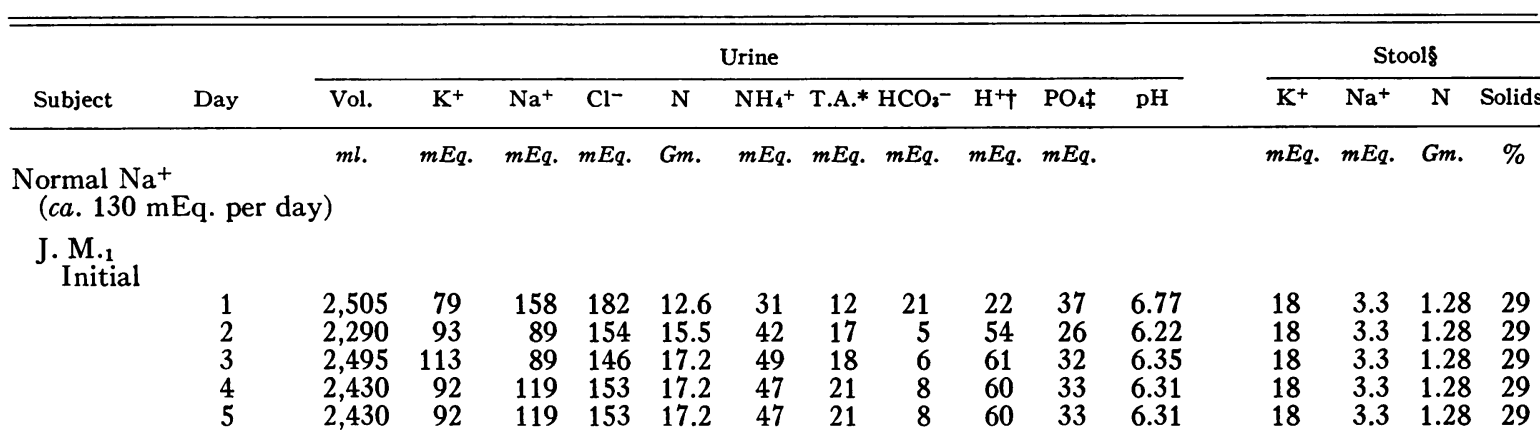

Depletion

(ca. $1 \mathrm{mEq} \cdot$ per day)

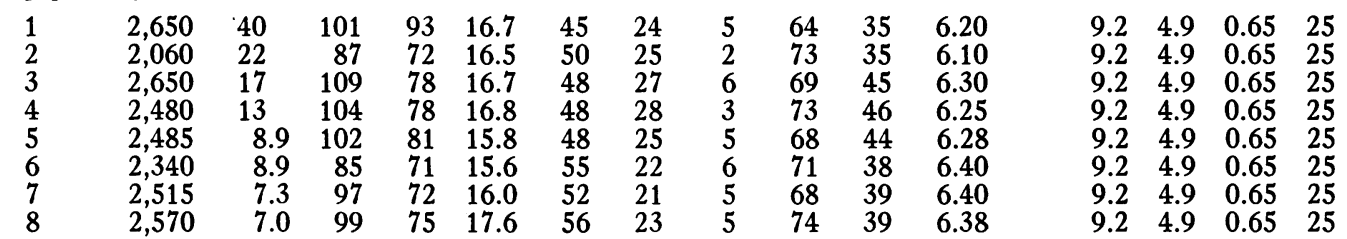

Depletion + DCA (20 mg. per day)

\begin{tabular}{|c|c|c|c|c|c|c|c|c|c|c|c|c|c|c|}
\hline $\begin{array}{r}9 \\
10 \\
11 \\
12 \\
13\end{array}$ & $\begin{array}{l}2,380 \\
2,015 \\
2,550 \\
2,495 \\
2,040\end{array}$ & $\begin{array}{l}14 \\
15 \\
11 \\
16 \\
13\end{array}$ & $\begin{array}{l}40 \\
26 \\
64 \\
68 \\
47\end{array}$ & $\begin{array}{l}48 \\
35 \\
65 \\
71 \\
41\end{array}$ & $\begin{array}{l}18.0 \\
18.0 \\
17.9 \\
17.6 \\
17.6\end{array}$ & $\begin{array}{l}80 \\
76 \\
72 \\
77 \\
72\end{array}$ & $\begin{array}{l}28 \\
24 \\
25 \\
19 \\
23\end{array}$ & $\begin{array}{l}3 \\
2 \\
4 \\
6 \\
5\end{array}$ & $\begin{array}{r}105 \\
98 \\
93 \\
90 \\
90\end{array}$ & $\begin{array}{l}37 \\
36 \\
35 \\
34 \\
30\end{array}$ & $\begin{array}{l}6.10 \\
6.20 \\
6.20 \\
6.43 \\
6.17\end{array}$ & $\begin{array}{l}9.5 \\
9.5 \\
9.5 \\
9.5 \\
9.5\end{array}$ & $\begin{array}{l}2 . \\
2 . \\
2 . \\
2 . \\
2 .\end{array}$ & $\begin{array}{l}0.54 \\
0.54 \\
0.54 \\
0.54 \\
0.54\end{array}$ \\
\hline
\end{tabular}

High $\mathrm{Na}^{+}$intake

(ca. $348 \mathrm{mEq}$. per day)

J. M.2

Initial

\begin{tabular}{|c|c|c|c|c|c|c|c|c|c|c|c|c|c|c|}
\hline $\begin{array}{l}1 \\
2 \\
3 \\
4\end{array}$ & $\begin{array}{l}1,965 \\
2,045 \\
3,040 \\
3,355 \\
2,240\end{array}$ & $\begin{array}{r}60 \\
94 \\
144 \\
112 \\
97\end{array}$ & $\begin{array}{l}257 \\
284 \\
383 \\
388 \\
280\end{array}$ & $\begin{array}{l}214 \\
288 \\
381 \\
390 \\
276\end{array}$ & $\begin{array}{l}10.7 \\
13.3 \\
16.1 \\
16.9 \\
16.6\end{array}$ & $\begin{array}{l}15 \\
26 \\
23 \\
28 \\
30\end{array}$ & $\begin{array}{r}4 \\
10 \\
5 \\
9 \\
9\end{array}$ & $\begin{array}{l}39 \\
25 \\
57 \\
39 \\
30\end{array}$ & $\begin{array}{r}-20 \\
11 \\
-29 \\
-\quad 2 \\
9\end{array}$ & $\begin{array}{l}46 \\
39 \\
55 \\
43 \\
40\end{array}$ & $\begin{array}{l}7.17 \\
6.80 \\
7.17 \\
6.98 \\
6.97\end{array}$ & $\begin{array}{l}9.2 \\
9.2 \\
9.2 \\
9.2 \\
9.2\end{array}$ & $\begin{array}{l}4.9 \\
4.9 \\
4.9 \\
4.9 \\
4.9\end{array}$ & $\begin{array}{l}0.84 \\
0.84 \\
0.84 \\
0.84 \\
0.84\end{array}$ \\
\hline
\end{tabular}

Depletion

(ca. $1 \mathrm{mEq}$. per day)

\begin{tabular}{|c|c|c|c|c|c|c|c|c|c|c|c|c|c|}
\hline $\begin{array}{l}1,770 \\
2,665 \\
2,230 \\
1,960 \\
2,330 \\
3,285 \\
2,650\end{array}$ & $\begin{array}{l}50 \\
37 \\
20 \\
16 \\
15 \\
11 \\
12\end{array}$ & $\begin{array}{l}229 \\
327 \\
292 \\
238 \\
259 \\
364 \\
305\end{array}$ & $\begin{array}{l}183 \\
230 \\
221 \\
177 \\
219 \\
281 \\
248\end{array}$ & $\begin{array}{l}16.8 \\
16.3 \\
16.4 \\
15.9 \\
16.7 \\
16.2\end{array}$ & $\begin{array}{l}35 \\
30 \\
31 \\
33 \\
40 \\
34\end{array}$ & $\begin{array}{r}12 \\
8 \\
11 \\
12 \\
8 \\
5\end{array}$ & $\begin{array}{l}15 \\
33 \\
24 \\
15 \\
20 \\
42\end{array}$ & $\begin{array}{r}32 \\
5 \\
18 \\
30 \\
28 \\
-\quad 3\end{array}$ & $\begin{array}{l}50 \\
53 \\
50 \\
43 \\
37 \\
46 \\
43\end{array}$ & $\begin{array}{l}6.82 \\
7.03 \\
6.90 \\
6.80 \\
6.97 \\
7.16 \\
7.00\end{array}$ & $\begin{array}{l}5.5 \\
5.5 \\
5.5 \\
5.5 \\
5.5 \\
5.5 \\
5.5\end{array}$ & $\begin{array}{l}3.6 \\
3.6 \\
3.6 \\
3.6 \\
3.6 \\
3.6 \\
3.6\end{array}$ & $\begin{array}{l}0.46 \\
0.46 \\
0.46 \\
0.46 \\
0.46 \\
0.46 \\
0.46\end{array}$ \\
\hline
\end{tabular}

Depletion + DCA (20 mg per day)

\begin{tabular}{|c|c|c|c|c|c|c|c|c|c|c|c|c|c|c|c|}
\hline $\begin{array}{r}8 \\
9 \\
10 \\
11 \\
12\end{array}$ & $\begin{array}{l}1,935 \\
2,535 \\
2,570 \\
1,560 \\
1,725\end{array}$ & $\begin{array}{l}19 \\
23 \\
23 \\
19 \\
28\end{array}$ & $\begin{array}{l}192 \\
271 \\
299 \\
205 \\
176\end{array}$ & $\begin{array}{l}179 \\
211 \\
251 \\
168 \\
156\end{array}$ & $\begin{array}{l}16.3 \\
16.7 \\
16.3 \\
14.5 \\
15.5\end{array}$ & $\begin{array}{l}61 \\
49 \\
52 \\
55 \\
54\end{array}$ & $\begin{array}{r}17 \\
6 \\
9 \\
8 \\
8\end{array}$ & $\begin{array}{r}6 \\
33 \\
31 \\
17 \\
20\end{array}$ & $\begin{array}{l}72 \\
22 \\
30 \\
46 \\
42\end{array}$ & $\begin{array}{l}38 \\
46 \\
47 \\
42 \\
32\end{array}$ & $\begin{array}{l}6.52 \\
7.12 \\
7.00 \\
6.92 \\
6.90\end{array}$ & $\begin{array}{l}6.4 \\
6.4 \\
6.4 \\
6.4 \\
6.4\end{array}$ & $\begin{array}{l}0.8 \\
0.8 \\
0.8 \\
0.8 \\
0.8\end{array}$ & $\begin{array}{l}0.38 \\
0.38 \\
0.38 \\
0.38 \\
0.38\end{array}$ & $\begin{array}{l}22 \\
22 \\
22 \\
22 \\
22\end{array}$ \\
\hline
\end{tabular}

* Titratable acid, T.A.

$\dagger$ Total hydrogen, $\mathrm{H}^{+},=\left(\mathrm{NH}_{4}^{+}+\right.$T.A. $\left.-\mathrm{HCO}_{3}^{-}\right)$.

$\ddagger$ Phosphate expressed in terms of base requirement for excretion at given $\mathrm{pH}$.

$\$$ Chloride in stool averaged $0.3,1.1$ and $0.6 \mathrm{mEq}$. per day, respectively, for the three experimental periods.

II Chloride in stool averaged $0.9,0.6$ and $0.4 \mathrm{mEq}$. per day for the three experimental periods, respectively.

7 Chloride in stool averaged $0.1,0.4,0$ and $1.0 \mathrm{mEq}$. per day for the initial and three depletion periods, respectively.

** Chloride in stool averaged $2.0 \mathrm{mEq}$. per day for the initial period and the first six days of the depletion period and $1.0 \mathrm{mEq}$. per day for the rest of the experiment. 
TABLE II-Continued

\begin{tabular}{|c|c|c|c|c|c|c|c|c|c|c|c|c|c|c|c|c|}
\hline \multirow[b]{2}{*}{ Subject } & \multirow[b]{2}{*}{ Day } & \multicolumn{11}{|c|}{ Urine } & \multicolumn{4}{|c|}{ Stool $\uparrow$} \\
\hline & & Vol. & $\mathbf{K}^{+}$ & $\mathrm{Na}^{+}$ & $\mathrm{Cl}^{-}$ & $\mathbf{N}$ & $\mathrm{NH}_{4}{ }^{+}$ & T.A.* & $\mathrm{HCO}_{3}-$ & $\mathrm{H}^{+} \dagger$ & PO4 & $\mathrm{pH}$ & $\mathrm{K}^{+}$ & $\mathrm{Na}^{+}$ & $\mathbf{N}$ & Solids \\
\hline \multirow{3}{*}{ R. Initial $^{H}$} & & $m l$. & $m E q$. & $m E q$. & $m E q$. & $\mathrm{Gm}$. & $m E q$. & $m E q$. & $m E q$. & $m E q$. & $m E q$. & & $m E q$. & $m E q$. & $G m$. & $\%$ \\
\hline & $\begin{array}{l}1 \\
2\end{array}$ & $\begin{array}{l}1,710 \\
\text { (specin }\end{array}$ & $\begin{array}{l}96 \\
\text { en lost }\end{array}$ & t) 255 & 266 & 14.9 & 25 & 12 & 19 & 18 & 29 & 6.70 & $\begin{array}{l}7.5 \\
7.5\end{array}$ & $\begin{array}{l}1.5 \\
1.5\end{array}$ & $\begin{array}{l}0.8 \\
0.8\end{array}$ & $\begin{array}{l}36 \\
36\end{array}$ \\
\hline & $\begin{array}{l}3 \\
4 \\
5\end{array}$ & $\begin{array}{l}2,500 \\
2,830 \\
2,840\end{array}$ & $\begin{array}{l}78 \\
88 \\
88\end{array}$ & $\begin{array}{l}336 \\
410 \\
368\end{array}$ & $\begin{array}{l}325 \\
387 \\
350\end{array}$ & $\begin{array}{l}14.9 \\
16.6 \\
16.0\end{array}$ & $\begin{array}{l}21 \\
29 \\
21\end{array}$ & $\begin{array}{l}5 \\
5 \\
9\end{array}$ & $\begin{array}{l}31 \\
60 \\
37\end{array}$ & $\begin{array}{l}-5 \\
-26 \\
-7\end{array}$ & $\begin{array}{l}32 \\
39 \\
35\end{array}$ & $\begin{array}{l}7.05 \\
7.10 \\
6.93\end{array}$ & $\begin{array}{l}7.5 \\
7.5 \\
7.5\end{array}$ & $\begin{array}{l}1.5 \\
1.5 \\
1.5\end{array}$ & $\begin{array}{l}0.8 \\
0.8 \\
0.8\end{array}$ & $\begin{array}{l}36 \\
36 \\
36\end{array}$ \\
\hline
\end{tabular}

Depletion

(ca. $1 \mathrm{mEq}$. per day)

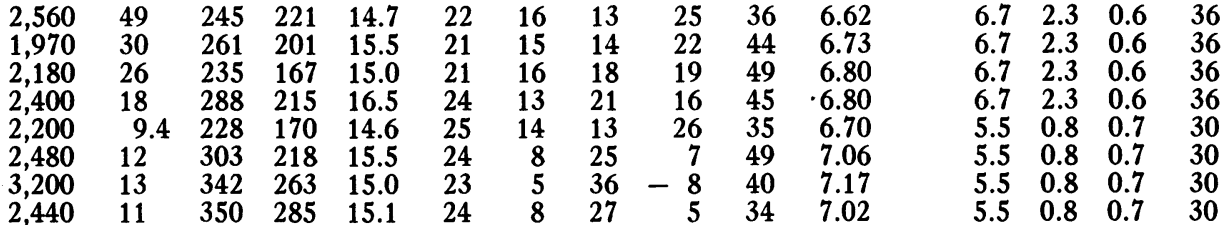

Depletion + DCA (20 mg. per day)

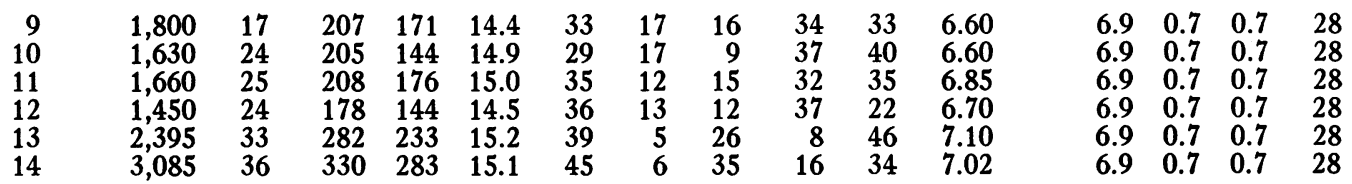

Depletion

$\begin{array}{lcccccccccccccccc}15 & 2,180 & 10 & 276 & 154 & 13.0 & 27 & 1 & 37 & -9 & 28 & 7.35 & & 5.0 & 4.0 & 0.7 & 18 \\ 16 & 2,820 & 9.9 & 381 & 265 & 14.0 & 30 & 0 & 55 & -25 & 45 & 7.40 & & 5.0 & 4.0 & 0.7 & 18\end{array}$

Repletion (215 mEq. $\mathrm{K}^{+}$per day)

$$
\begin{array}{llllllllllll}
1 & 2,750 & 28 & 591 & 470 & 16.4 & 24 & 0 & 85 & -61 & 35 & 7.48 \\
2 & 3,600 & 79 & 666 & 615 & 15.3 & 24 & 0 & 72 & -48 & 24 & 7.40
\end{array}
$$

J.S.

Initial

$\begin{array}{rrrrrrrrrrrrrrrr}1 & 1,250 & 78 & 214 & 218 & 16.6 & 40 & 13 & 4 & 49 & 36 & 6.00 & 30 & 17 & 2.4 & 12 \\ 2 & 2,335 & 85 & 292 & 333 & 18.1 & \mathbf{5 2} & 25 & 5 & 72 & 38 & 6.18 & 30 & 17 & 2.4 & 12 \\ 3 & 2,810 & 88 & 342 & 370 & 16.9 & 46 & 17 & 14 & 49 & 42 & 6.58 & 30 & 17 & 2.4 & 12 \\ 4 & 2,260 & 82 & 306 & 325 & 16.2 & \mathbf{4 7} & 22 & 8 & 61 & 38 & 6.36 & 30 & 17 & 2.4 & 12 \\ \mathbf{5} & 1,940 & \mathbf{8 2} & \mathbf{3 1 6} & \mathbf{3 0 4} & \mathbf{1 6 . 7} & \mathbf{5 0} & \mathbf{2 3} & \mathbf{7} & \mathbf{6 7} & \mathbf{3 7} & \mathbf{6 . 3 2} & \mathbf{3 0} & \mathbf{1 7} & 2.4 & 12\end{array}$

Depletion

(ca. $1 \mathrm{mEq}$. per day)

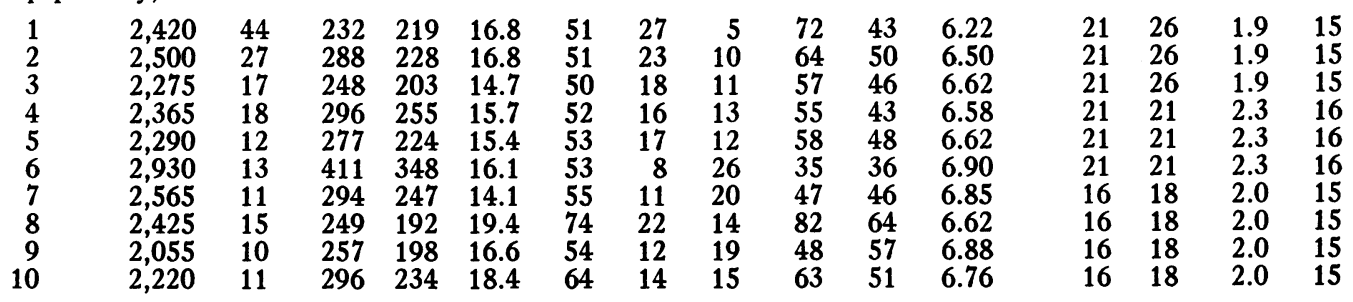

Depletion + DCA (20 mg. per day)

$\begin{array}{rrrrrrrrrrrrrrrr}11 & 2,125 & 19 & 242 & 212 & 17.8 & 73 & 19 & 8 & 84 & 45 & 6.56 & 24 & 4 & 1.6 & 17 \\ 12 & 2,105 & 22 & 225 & 192 & 18.2 & 77 & 17 & 14 & 81 & 51 & 6.70 & 24 & 4 & 1.6 & 17 \\ 13 & 2,060 & 18 & 242 & 220 & 17.0 & 80 & 15 & 16 & 79 & 42 & 6.68 & 24 & 4 & 1.6 & 17 \\ 14 & 2,440 & 18 & 275 & 254 & 15.9 & 81 & 16 & 20 & 77 & 39 & 6.75 & 24 & 4 & 1.6 & 17 \\ 15 & 2,790 & 17 & 349 & 317 & 15.5 & 84 & 8 & 36 & 55 & 40 & 7.02 & 24 & 4 & 1.6 & 17 \\ 16 & 2,090 & 15 & 234 & 212 & 15.0 & 80 & 11 & 25 & 66 & 41 & 6.82 & 24 & 4 & 1.6 & 17\end{array}$


corrected for negative nitrogen balance), the smallest deficit being in the subject on normal sodium intake (Table III).

All of the subjects had positive sodium and chloride balances (Table III). The ratio of sodium retained to chloride retained exceeded the dietary ratio of these two ions in each subject studied. The subject on a normal sodium intake showed a ratio of 2.1. Two of the subjects on high sodium intakes, J. M.2 and R. H., had ratios of 1.7 , while the third, J. S., had a ratio of 2.7. Sodium retained exceeded the amount of potassium lost. For the subject on normal sodium intake, the ratio of sodium retained to potassium lost was 2.1. For the subjects on high sodium intake, the ratio was 2.7 in two of the subjects and 1.5 in the third. The greatest positive sodium balance occurred during the DCA period, with drops in stool sodium output as well as in that of the urine.

All of the subjects had negative nitrogen balances despite adequate levels of protein intake (Table III). These balances ranged from -3.3 to $-38.8 \mathrm{Gm}$. for the total depletion periods (including DCA) of 12 to 16 days.

\section{Urinary excretion of acid}

In three studies (J. M.n J. M.2 and R. H.) urinary $p H$ showed no substantial changes (Table II). In the fourth study (J. S.) urinary $\mathrm{pH}$ rose as potassium depletion progressed.

The three major components affecting total acid excretion, namely, ammonium ion, titratable acidity (T.A.) and bicarbonate, showed greater

TABLE III

Cumulative balances of nitrogen and electrolytes *

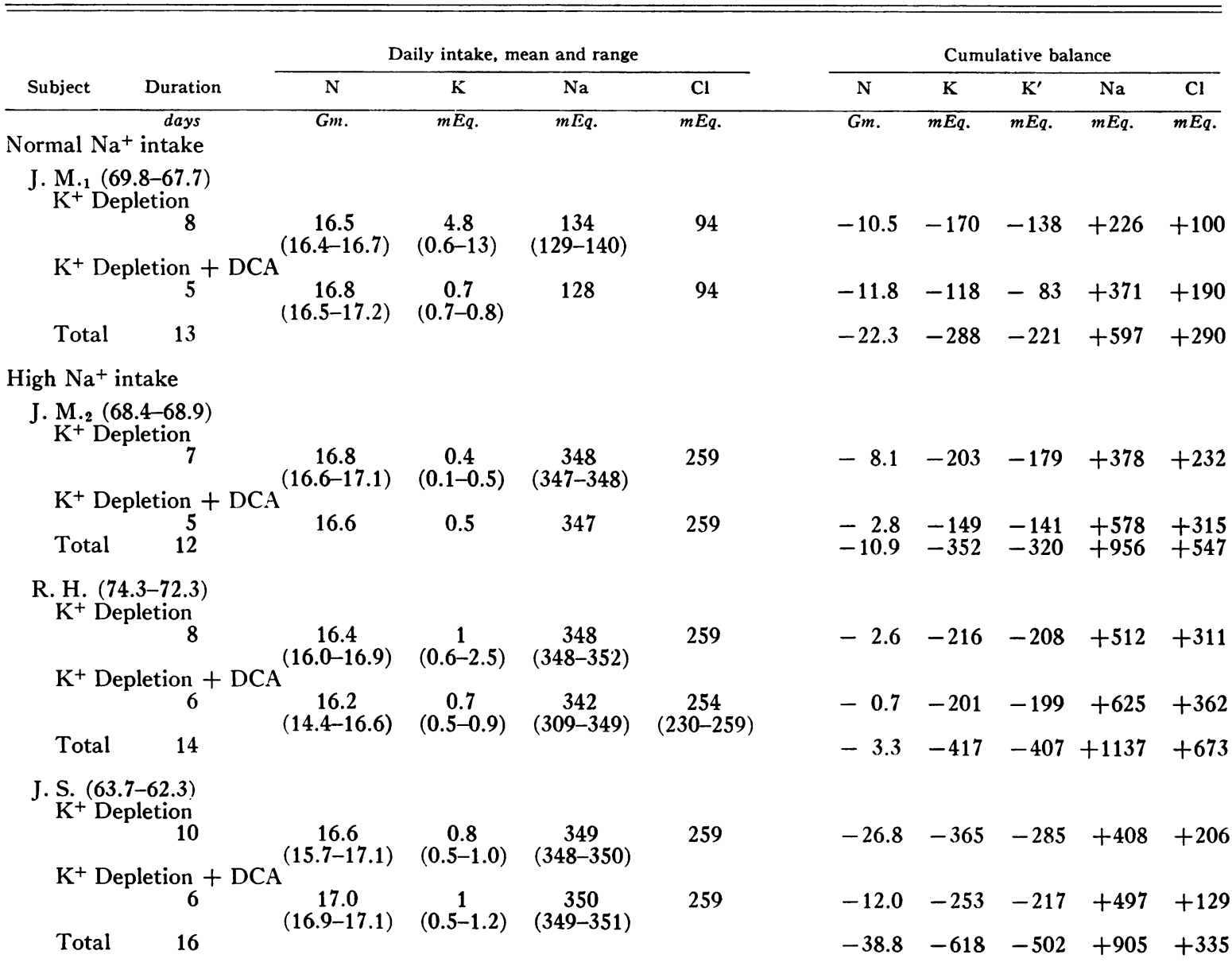

* Figures in parentheses after subject initials give body weights in $\mathrm{Kg}$. at the beginning and end of each study. 
changes (Figure 2). Titratable acidity showed no change or increased slightly after the predepletion period in three of the studies (J. M.1, J. M.2 and R. H.). The fourth study (J.S.) showed some decrease in the excretion of titratable acidity as the depletion progressed. In all of the studies ammonium ion excretion increased as depletion progressed and most strikingly so during DCA administration.

The net urinary acid or total effective hydrogen ion excretion ( $\mathrm{NH}_{4}{ }^{+}+$T.A. - $\left.\mathrm{HCO}_{3}^{-}\right)$(18) is shown in Figure 2 compared with the expected excretion as calculated from the predepletion period excretion and the changes in cation and anion intake (the only changes were in potassium chloride and bicarbonate). In general, the net acid excretion was slightly to greatly below the expected value during the potassium depletion prior to DCA administration. During the DCA period the net acid excretion rose in three of the subjects (J. M.1, J. M.2 and R. H.) above the expected value resulting in the retention of bicarbonate. In one subject, J. S., the urine continued to contain less acid than predicted but the decrement was not so great during the period of DCA administration. In R. H., during repletion, more bicarbonate was excreted and acid was conserved.

\section{Symptoms}

The subjects felt well, in general, throughout the studies. Some felt tired during the last few days, but they thought that this was due to boredom generated by the routine and confinement required by the study. One of the subjects, J. M., felt headache and nasal congestion

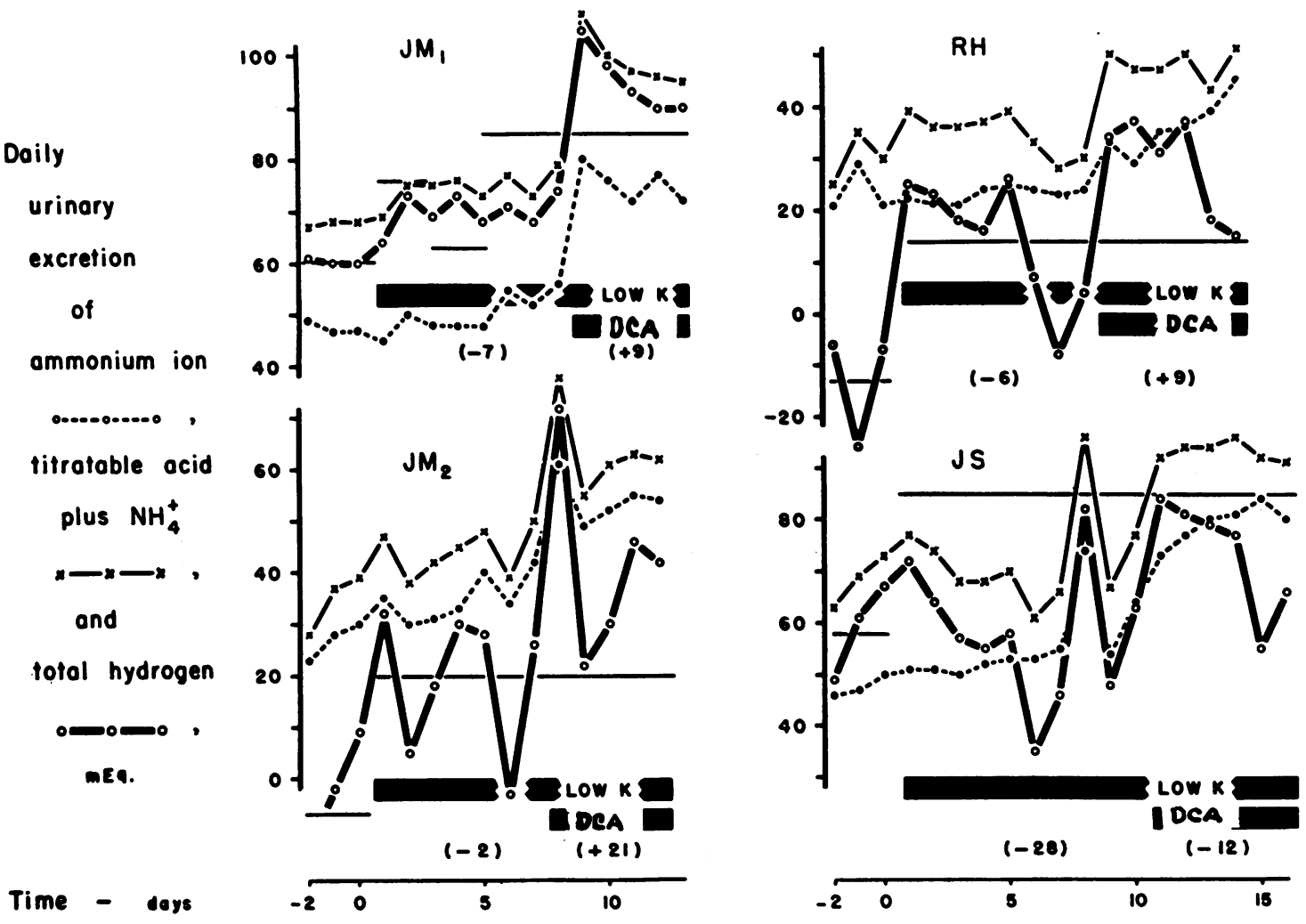

Fig. 2. The Daily Total Urinary Excretion of Acid and Components, Ammonium Ion and Titratable Acidity, During Potassium Deprivation and Administration of Desoxycorticosterone

The total acid excretion, $\Delta \mathrm{UV}_{\mathrm{H}^{+}}$, is calculated as $\Delta \mathrm{UV}_{\mathrm{NH}_{4}}{ }^{+}+\Delta \mathrm{UV}_{\text {T.A. }}-\Delta \mathrm{UV}_{\mathrm{HCO}_{2}-}$. The horizontal lines indicate the total acid excretion predicted from the values of the last three days of the control period and the change in intake of anions relative to cations (the only variation in this level, that in J. M.1, was due to diet change). The values in parentheses in each experimental period indicate the average daily difference between the actual acid excretion and that predicted from the dietary anion-cation balance and the control rate; during $\mathrm{K}$ deprivation alone less acid was excreted and DCA reversed or diminished this trend. 
in the last three days of the DCA period. Subject J.S. had a sensation of chilliness and muscle ache, without fever, during the sixth and seventh days of depletion; these symptoms were attributed to a mild incidental viral infection.

\section{RESULTS : DERIVED}

Relation of potassium deficit to blood $\mathrm{CO}_{2}$ content

Although only one subject (J.S.) developed an arterial total $\mathrm{CO}_{2}$ content significantly higher than the upper limit of normal (24 mMoles per L.), the other subjects did show a tendency to develop rising total $\mathrm{CO}_{2}$ levels in both venous serum and arterialized cutaneous whole blood as the severity of the potassium depletion increased and especially when DCA was given. This tendency is emphasized when $\mathrm{CO}_{2}$ values are plotted as increments above the last value of the predepletion period against the negative balance of potassium (Figure 3).
Analysis of internal transfers of water and electrolytes

Much of the subsequent interpretation depends in large part on the use of the chloride space calculation (17) for an estimate of extracellular fluid volume. The validity of this use has been argued for at least a decade and the authors cannot support either end of the argument from the data of this study. A recent thorough analysis of the chloride space problem by Cheek, West and Golden (19) has provided strong support for the close approximation of extracellular fluid volume in the rat by this method under normal circumstances. How good this approximation is for following sequential changes in human pathological situations is not clear. Possible sequestration of chloride-containing fluid in an atonic bowel may be an objection to the use of the chloride space in the presence of potassium depletion (20). Several roentgen studies of gastro-

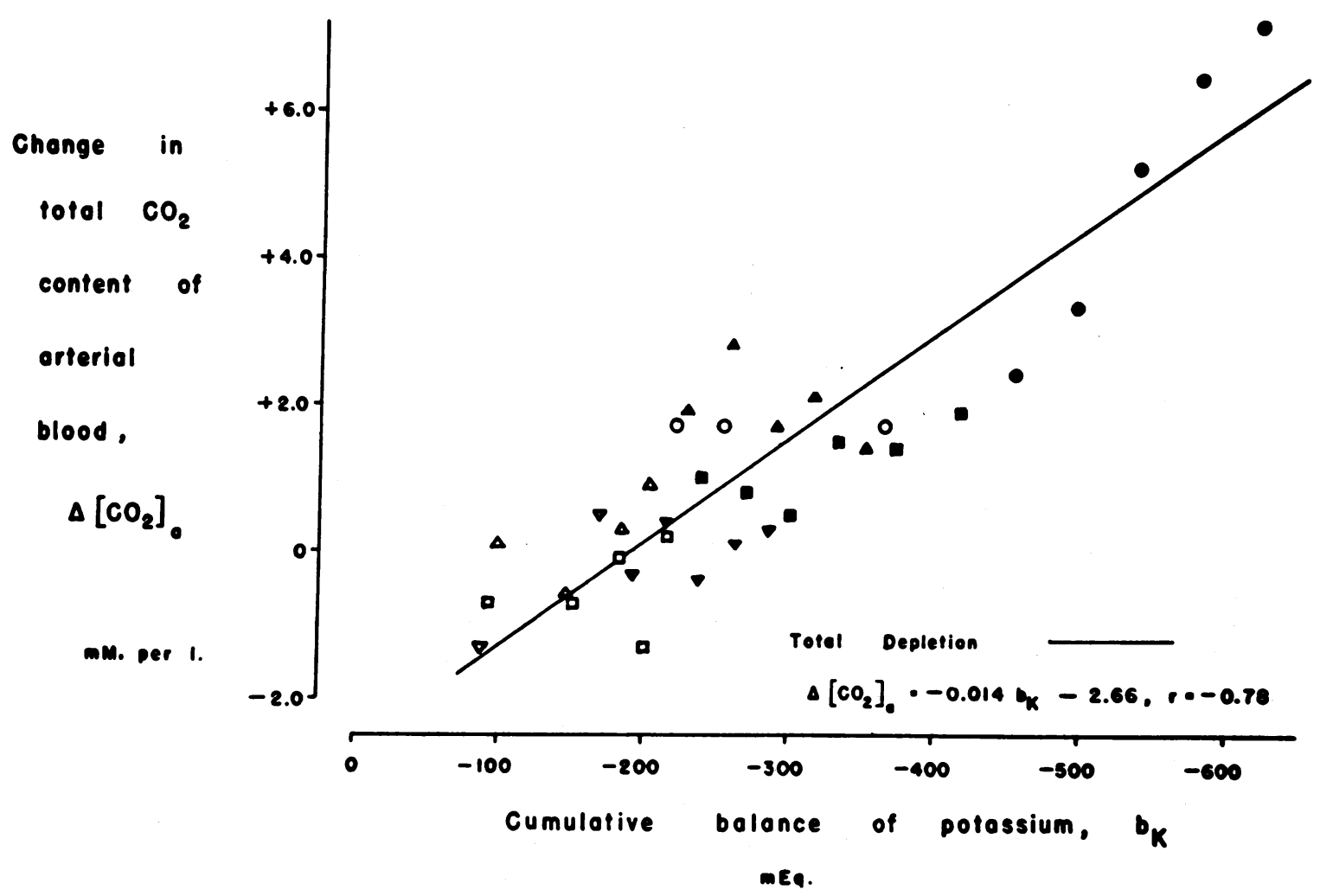

Fig. 3. The Regression of Change in Arterial Total $\mathrm{CO}_{2}$ Content on the Cumulative Potassium Deficit

Symbols are for the different subjects, open symbols representing pre-DCA periods and solid symbols representing those of DCA administration.

The negative correlation is good although the changes in arterial $\mathrm{CO}_{2}$ content are not large. 


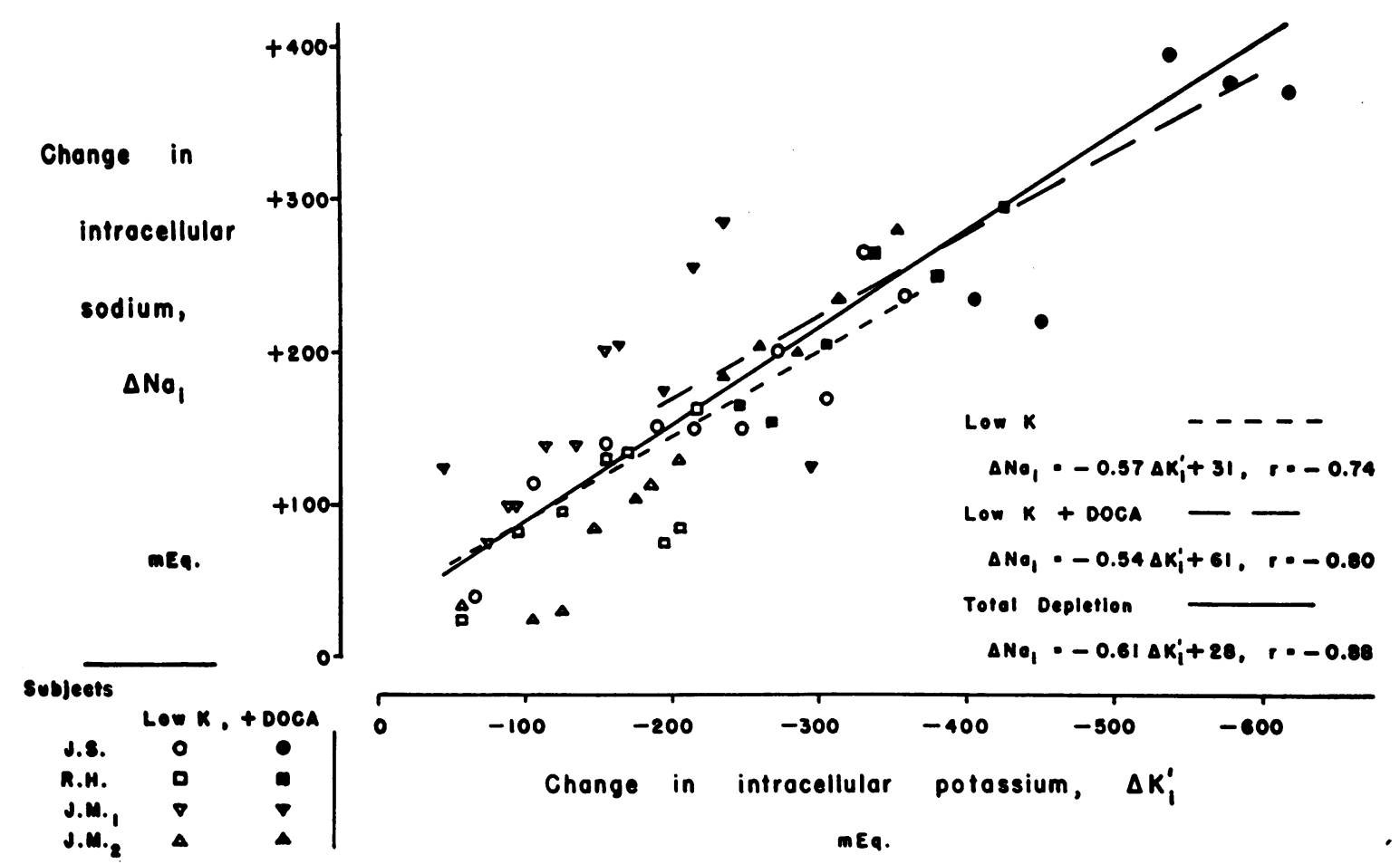

Fig. 4. Regression of Calculated Cumulative Increase of Intracellular Sodium on Calculated Cumulative Deficit of Intracellular Potassium

The relationship is close to that predicted $(+2:-3)$ by the Darrow findings in rat skeletal muscle (see text) and is the same during potassium deprivation without DCA and with DCA. Symbols are as in Figure 3.

intestinal function in the subjects of a previous experiment (1) failed to show such a disturbance. The authors have proceeded to use the chloride space as an arbitrary theoretical foundation fully aware of the other uncertainties involved.

In assessing the water metabolism in this study, approximations of the total body water were derived from the assumption that total body water weight equalled 74 per cent of the lean body mass at the beginning of the depletion period. Lean body mass was calculated from the daily creatinine excretion during the control periods by the formula of Miller and Blyth (21). Changes in total body water were derived from the formula of Peters (17). The initial extracellular fluid volume was arbitrarily assumed to be 28 per cent of the total body water and changes in the extracellular fluid volume were equated with changes in the chloride space. The difference between total body water and extracellular water (chloride space) was taken as intracellular water. All of the subjects maintained total body water close to normal, one of them (J.S.) showing a slight and probably insignificant decline. The chloride space expanded by 30 to 50 per cent of the original value (an expansion equal to 5 to 10 per cent of the original lean body mass) in all of the subjects, the expansion being greatest during the administration of desoxycorticosterone. As a result, the intracellular water volume was calculated to have decreased by approximately 12 to 15 per cent of its original value. Calculated insensible water losses were similar among the subjects, all of whom had practically the same estimated lean body mass (about $\mathbf{5 7 . 0}$ $\mathrm{Kg}$.). The average losses and their ranges were: $1.45 \mathrm{~L}$. per day in the control period (1.37 to $1.53) ; 1.28$ in the initial potassium depletion period (1.22 to 1.37$)$; and 1.26 in the depletion and DCA period (1.11 to 1.34). These values are higher than for basal subjects because of the normal activity allowed the subjects. The differences among the periods are not statistically significant owing to the small number of data. 


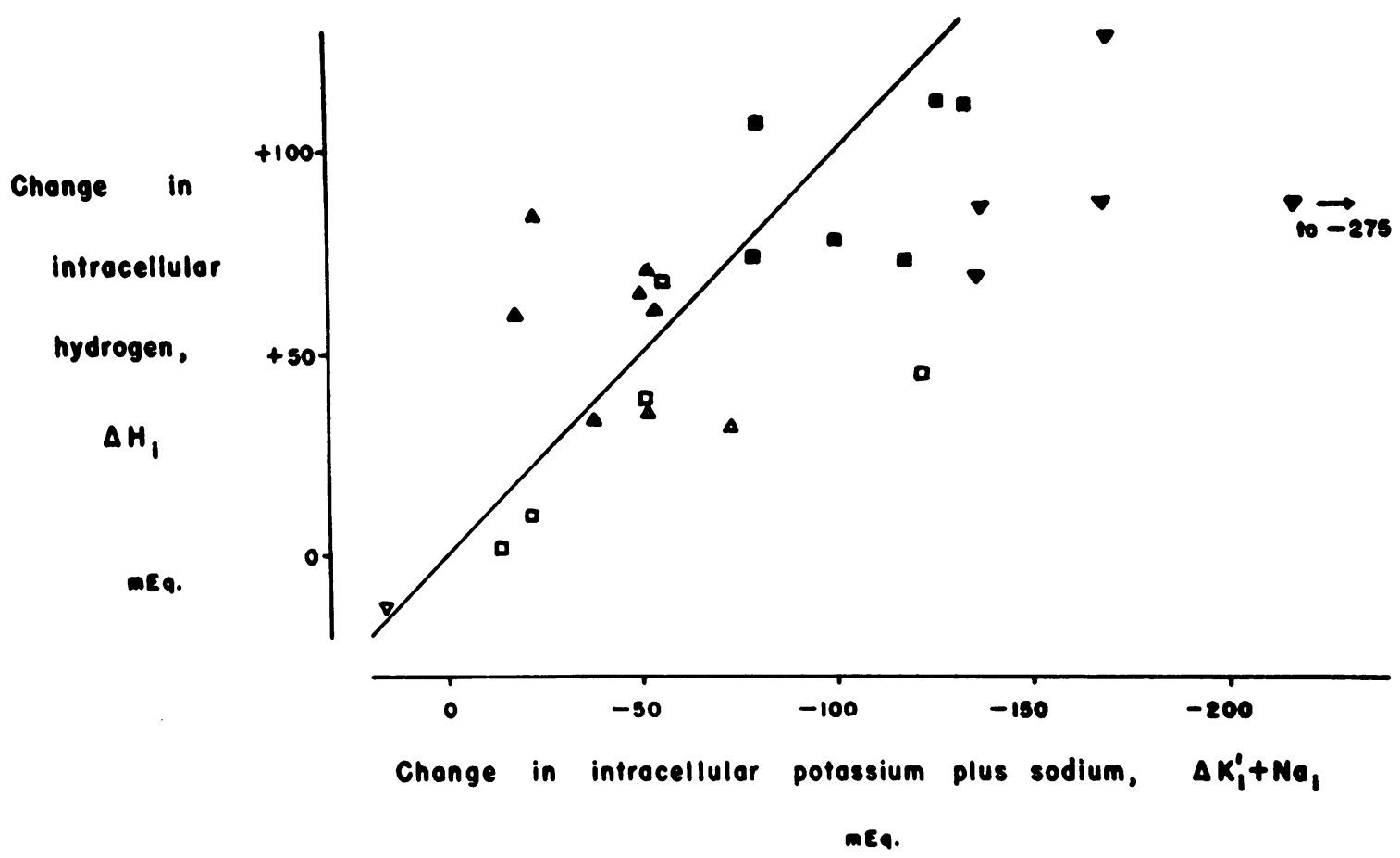

Fig. 5. Comparison of Calculated Cumulative Increment of Intracellular Hydrogen with the Calculated Cumulative Deficit of Intracellular Potassium Not Replaced by Sodium

The line indicates a theoretical $1: 1$ ratio. In three of the subjects such a relationship approximately obtained; in the fourth, J. S., $\Delta \mathrm{H}_{\mathrm{i}}$ greatly exceeded $-\Delta \mathrm{K}_{\mathrm{i}}+\Delta \mathrm{Na}_{\mathrm{i}}$ and the data are not plotted (see text). Symbols are as in Figure 3.

\section{Internal transfers of potassium and sodium}

In each subject the intracellular phase progressively lost potassium in excess of nitrogen and gained sodium. The quantitative relationships of these exchanges are shown in Figure 4. The regression line with a regression coefficient of 0.61 demonstrates that these subjects as a group showed the phenomenon of replacement of approximately two-thirds of the potassium loss by sodium, as found by Darrow, Schwartz, Iannucci and Coville (2) in rats. This $2: 3$ ratio was the same during potassium depletion alone and during depletion plus DCA administration.

\section{Internal transfers of hydrogen and bicarbonate}

These transfers were derived by the method of calculation previously reported by Elkinton, Singer, Barker and Clark (22); the details of this approach and its validation will not be discussed here. Briefly, movements of hydrogen ${ }^{2}$ in one

2 "Hydrogen" as used here refers to both the ionized form and to the vastly larger quantities present in the weak direction with respect to the intracellular phase $\left(\Delta \mathrm{H}_{\mathrm{i}}\right)$ (or equivalent movements of bicarbonate in the opposite direction) are calculated from the change in total amount of extracellular plus red cell bicarbonate $\left(\mathrm{HCCO}_{3}{ }^{-}\right.$er $)$corrected for the change in hydrogen in the protein nonbicarbonate buffers of the blood $\left(\Delta \mathrm{H}^{+}\right.$buf $)$and for the external balance of hydrogen $\left(\mathrm{b}_{\mathrm{H}}{ }^{+}\right)$:

$$
\Delta \mathrm{H}_{\mathrm{i}}{ }^{+}=\Delta \mathrm{HCO}_{3}^{-}{ }_{\text {er }}+\Delta \mathrm{H}^{+}{ }_{\text {buf }}+\mathrm{b}_{\mathrm{H}^{+}}
$$

The external balance of hydrogen is derived by comparing the change in urinary excretion of hydrogen $\left(\Delta \mathrm{UV}_{\mathrm{H}^{+}}\right)$, calculated as the sum of changes in excretion of titratable acid plus ammonium ion minus bicarbonate $\left(\Delta \mathrm{UV}_{\mathrm{TA}}+\Delta \mathrm{UV}_{\mathrm{NH}_{4}}{ }^{+}\right.$ $\left.-\Delta \mathrm{UV}_{\mathrm{HCO}_{3}}{ }^{-}\right)$, with the change in the acid content of the diet which accompanied the with-

acids of buffer systems; the gaseous form is not implied. Possible changes in $\mathrm{CO}_{2}$ production do not have significance in this calculation; the rigid control of dietary intake practically excludes changes in acid production (see Reference 22). 
drawal of potassium supplement from the prepared diet.

In Figure 5, changes in intracellular hydrogen $\left(\Delta \mathrm{H}_{\mathrm{i}}{ }^{+}\right)$, so calculated, are compared with the algebraic sums of the simultaneous derived changes in intracellular potassium and sodium in three of the four subjects. The relationship is not far from that of $1: 1$ as predicted by Darrow and suggests the development of an intracellular acidosis. In the fourth subject, J.S., the increments of cellular hydrogen so far exceeded the loss of potassium against sodium gained that the data are not plotted.

\section{Relations of renal acid excretion, intracellular acid-} base changes and extracellular alkalosis

During the development of potassium depletion before the DCA period, extracellular bicar- bonate or total buffer anion $\left(\Delta \mathrm{BB}_{\mathrm{er}}=\Delta \mathrm{HCO}_{3}{ }_{\text {er }}\right.$ $+\Delta \mathrm{H}^{+}{ }_{\text {buf }}$ ) increased (Figure 6), but the simultaneous increase in extracellular (chloride) space led to only small increases in extracellular bicarbonate concentration (Figure 1). At the same time, the cumulative renal excretion of acid ran close to or below that predicted from the predepletion period excretion and the withdrawal of potassium salts (Figure 2). The net effect of this renal response was to increase the calculated intracellular hydrogen content (Figure 6) in Subjects J. M.1 and J.S. In Subjects J. M.2 and R. H., the effect was to make no substantial change in extracellular or intracellular acid-base balance and the extracellular accumulation of total buffer anion was practically attributable to a new equilibrium established in the distribution

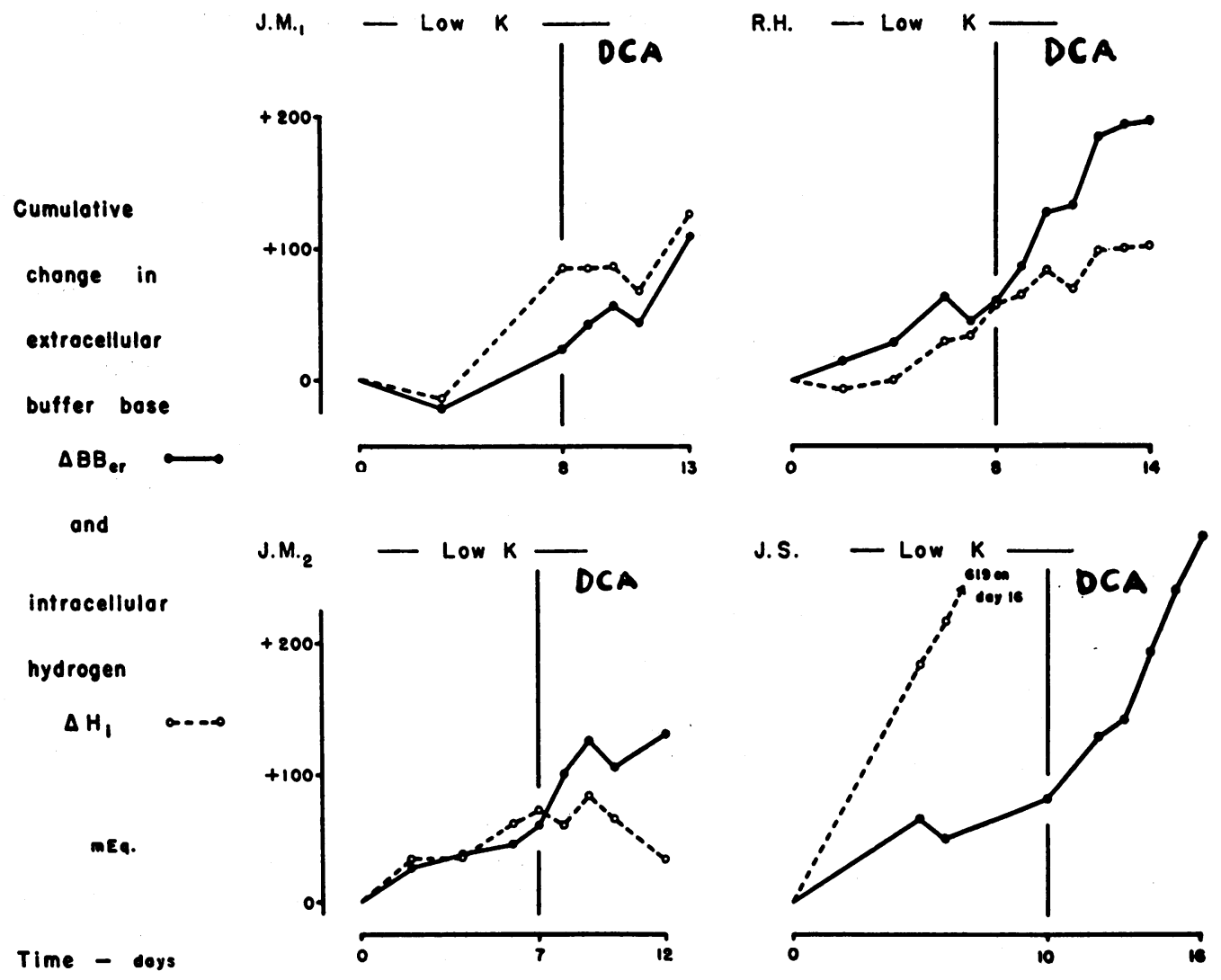

Fig. 6. Relation Between the Cumulative Change in Total Extracellular Buffer Base or Anion (Bicarbonate Plus Proteinate, $\left.\Delta \mathrm{BB}_{\mathrm{or}}\right)$ and in Intracellular Hydrogen $\left(\Delta \mathrm{H}_{\mathbf{i}}\right)$

The difference between the two represents the cumulative renal excretion of acid. When $\Delta \mathrm{H}_{\mathbf{i}}$ equals $\Delta \mathrm{BB}_{\mathrm{er}}$, the change in $\Delta \mathrm{BB}_{\text {er }}$ can be attributed to a redistribution of hydrogen ion between intracellular and extracellular compartments. When $\Delta \mathrm{H}_{\mathrm{i}}$ rises toward or exceeds $\Delta \mathrm{BB}_{\mathrm{er}}$, the kidney has excreted less acid or more alkali than predicted; when $\Delta \mathrm{H}_{\mathrm{i}}$ falls toward or below $\Delta \mathrm{BB}_{\mathrm{er}}$, the converse holds. DCA appears to promote this later change, affecting primarily $\Delta \mathrm{H}_{\mathrm{i}}$ rather than $\Delta \mathrm{BB}_{\mathrm{er}}$ which remained proportional to the cumulative potassium deficit. 
of bicarbonate and hydrogen between intracellular and extracellular compartments.

During the administration of DCA, the renal excretion of acid ran either above that predicted or, in the case of J. S., above the previous values (Figure 2). At the same time, the net result of extracellular accumulation of total buffer anion and increase in chloride space was only a modest additional rise in extracellular bicarbonate concentration in three subjects (J. M.1, J. M.2 and R. H.). In these three subjects, the major effect of this increase in acid excretion was to reduce the absolute intracellular hydrogen content or reduce its rate of increase. In the fourth subject, J. S., a sharper increase in serum bicarbonate concentration took place and the increased renal excretion of acid may have contributed to this because the rate of transfer of hydrogen into cells was essentially unchanged.

The examination of the relation between increments in extracellular total $\mathrm{CO}_{2}$ concentration (and $\mathrm{HCO}_{3}^{-}$) and the deficit of potassium (Figure 3 ) in the light of the preceding paragraphs suggests that the major effect of the kidney was a change in the intracellular acid-base pattern, and that the extracellular bicarbonate content held a relatively fixed relation to the size of the depletion little modified by renal acid-base excretion.

For Subject J. S. the results of these calculations do not agree entirely with the Darrow hypothesis. The cumulative change in extracellular buffer anion $\left(\Delta \mathrm{BB}_{\text {er }}\right)$ shows a fair agreement with the deficit of cellular potassium over sodium $\left[-\left(\Delta \mathrm{K}_{\mathbf{i}}+\Delta \mathrm{Na}_{\mathbf{i}}\right)\right]$, the respective values at the end of the depletion period without DCA and at the end of the DCA period being +80 and +120 , and +281 and $+241 \mathrm{mEq}$. However, because the urine output of acid consistently ran below that predicted (Figure 2), the calculated changes in intracellular hydrogen $\left(\Delta \mathrm{H}_{\mathrm{i}}\right)$ ran far higher than the calculated cellular cation deficit $\left[-\left(\Delta \mathrm{K}_{\mathrm{i}}+\mathrm{Na}_{\mathrm{i}}\right)\right]$, the respective figures for the two periods being +350 and +120 , and +619 and +241 , and far higher than the accumulation of extracellular buffer anion (Figure 6).

\section{DISCUSSION}

Many of the findings of this study agree with those of previous experimental human potassium depletions $(1,13,14,23,24)$. The degree of hy- pokalemia in relation to the size of the total depletion, i.e., a serum level of $3.0 \mathrm{mEq}$. per L. related to a depletion of 300 to $400 \mathrm{mEq}$., agrees well with findings of Black and Milne (13) and of Scribner and Burnell (25). The absence of definite symptoms (even at a depletion of 600 $\mathrm{mEq}$.) has been noted $(13,14,23)$. The expansion of extracellular fluid (chloride space) and inferred contraction of intracellular fluid volume have been described in experimental depletions in human subjects $(13,14)$ and in comparable depletions of the rat in which $\mathrm{NaCl}$ rather than $\mathrm{NaHCO}_{3}$ was the chief salt in the intake as in Group 5 of Cheek and West (11). Hence, these aspects of the problem will not be discussed further.

However, our data should help to clarify the relationship between potassium depletion and extracellular metabolic alkalosis in man. The Darrow hypothesis, as referred to in the introduction and later elaborations of it, is the most inclusive explanation to date of this association. This hypothesis holds that the development of an intracellular potassium deficit and the failure of sodium to entirely replace this deficit lead to an equilibrium shift of hydrogen into cells (or outward shift of bicarbonate) with the development of a lower $\mathrm{pH}$ within cells and a higher $\mathrm{pH}$ and bicarbonate level in extracellular fluid. The kidney is said to be unable to correct the extracellular alkalosis because the decline in availability of tubular potassium ion for exchange for sodium reabsorption or because an increased hydrogen content of the tubular cells leads the kidney to continue to excrete more acid than required by the extracellular acid-base situation. Recent experimental evidence supports this interpretation. Roberts, Randall, Sanders and Hood (26) found that the administration of potassium chloride to dogs with high $\mathrm{pCO}_{2}$ levels reduced the elevated tubular reabsorption of bicarbonate without change in the $\mathrm{pCO}_{2}$. Anderson and Mudge (27) by direct observations in vitro of kidney slices from potassium-depleted rabbits found a direct correlation between the potassium content and the bicarbonate content of the slices. These studies were interpreted to show that renal tubular reabsorption of bicarbonate and excretion of hydrogen are augmented by potassium depletion presumably by an increase in acidity of the renal tubular cell. 
With respect to the renal maintenance of the abnormal steady state of extracellular alkalosis, our data do not support the above hypothesis, since all our subjects in this study excreted less rather than more hydrogen during potassium depletion alone. This is discussed below. With respect to the internal shifts of cations, however, our derived data, considering the number and nature of the assumptions required, agree reasonably well with the Darrow hypothesis in three of the four studies (J.M.1, J. M.2 and R. H.), i.e., that the intracellular deficit of potassium was replaced by increments of sodium and hydrogen from extracellular fluid in the ratio of $2: 1$. In the other study, J. S., the calculations would suggest an increment of intracellular hydrogen far in excess of this ratio, though the sodium replacement was approximately twothirds of the potassium loss.

The type of acid-base analysis used here faces a number of criticisms. There are many possible sources of error in the estimation of change in intracellular hydrogen which have been discussed previously (22), but in the present analysis three primary difficulties are encountered. The first is that of selecting the acid excretion from the predepletion period urinary data which represents the attainment of equilibrium. This point is needed for the estimation of subsequent increments and decrements in acid excretion during depletion. An error of $5.0 \mathrm{mEq}$. in the selection of this point could lead to an error in the final estimation of cumulative $\Delta \mathrm{H}_{\mathrm{i}}{ }^{+}$of up to 100 per cent in these studies of duration 12 to 16 days. Later study has shown that the use of the average value for the third, fourth and fifth days of the predepletion period is justified as representing equilibrium (28). Endogenous protein catabolism proceeded at a substantially constant rate throughout each study, in the control and depletion periods; its effect on renal acid excretion, therefore, did not change.

The second primary difficulty faced in this analysis is the validity of the chloride space estimation of extracellular fluid volume. This question has been mentioned and the validity cannot be established further here. It should be noted that the Darrow hypothesis derived from analysis of muscle from potassium-depleted rats is also based on the assumptions implicit in the use of the chloride space. The present analysis is, however, open to the additional errors which may be involved in the estimation of chloride space changes from the cumulative data of the balance technique, and in the uncertainty of use of the chloride space calculation in the total body as contrasted with that in a single tissue. But this analysis lies within the same framework of reference and is pertinent to an investigation of the Darrow hypothesis. Nonetheless, the problem of potassium depletion and metabolic alkalosis still merits a study using a determination of extracellular fluid volume based on some other reference point.

The third question is that of the extent to which entry of sodium into intracellular volumes as estimated here can be considered synonymous with entry of sodium into cellular compartments losing potassium, an assumption applied to this analysis. No further evidence on the soundness of this assumption can be presented from this study and the possibility that some of the retained sodium is associated with bone rather than the intracellular volume of high potassium content cannot be denied.

With regard to the increment in $\mathrm{H}_{\mathrm{i}}$ in Subject J. S. which ran far higher than predicted from the Darrow hypothesis, several possibilities can be considered. First, if the acid excretion of the predepletion period had not decreased to equilibrium in the last three days, the estimate of expected acid excretion in the depletion period would be too high. Hence, calculations of retained acid would be erroneously high. This objection has been discussed above. Secondly, if the expected increase in acid excretion in depletion attendant on the decrease in bicarbonate ingestion were met by additional acid excretion via the phosphates of the bowel, this phenomenon could not be detected under the methods used in this study.

Change in extracellular volume, as well as total amount of extracellular bicarbonate or buffer anion, is a factor in determining its final bicarbonate concentration. Because the expansion of the chloride space was relatively small in Subject J.S., an increase in total amount of extracellular buffer anion only moderately larger than that in Subject J. M.2 and slightly less than that in Subject R. H. (Figure 6) resulted in a 
relatively large increase in concentration of buffer anion and bicarbonate (Figure 1). However, the failure of renal correction of extracellular alkalosis in the face of continued increments of intracellular acid, in part due to renal retention of acid, above that predicted by the Darrow hypothesis remains unexplained except for the suggestion of a fixed relation of obscure nature between total extracellular bicarbonate and intracellular potassium deficit referred to above.

In spite of the reasonable agreement of the data from Studies J. M.1, J. M.2 and R. H. with the hypothesis which has been discussed, the data from Study J. S. and data appearing in the literature on potassium depletion in animals suggest that this hypothesis may be an excessively simple description of the mode of development of metabolic alkalosis. First, the J.S. study data suggest an intracellular accumulation of hydrogen ion (or decrease in $\mathrm{HCO}_{3}^{-}$) far beyond that expected from the potassium deficit not replaced by sodium (vide supra) (even allowing for loss of acid via the stool). Of similar import are various data from the literature. In rats treated by Darrow, Schwartz, Iannucci and Coville with DCA and low potassium diets (2), groups of animals with the most severe alkalosis were among those with the smallest gap between potassium lost and sodium retained in muscle. Iacobellis, Muntwyler and Griffin (29) found the development of alkalosis in potassium-depleted dogs when losses of potassium from muscle were exceeded by sodium gain. Gardner, MacLachlan and Berman (7) found no decrease in total muscle fixed cation concentration in potassiumdepleted rats; they also noted an increase in inorganic phosphate concentration in the rat muscle. Black and Milne (13) estimated that their human subjects had an intracellular retention of phosphate relative to the potassium lost and found an increase in acid-soluble phosphate in erythrocytes. The possibility that in potassium depletion, amino acids, notably lysine, may function as cation replacement has been presented (30). All of these observations suggest that the increment in intracellular hydrogen ion concentration (7) which apparently develops in potassium depletion parallel to the extracellular metabolic alkalosis cannot be simply described by the discrepancy between potassium lost and sodium gained intracellularly but may also be related to changes in the concentration and valency of intracellular anions and to the functioning of amino acids as cations.

Another aspect of the problem of potassium depletion and metabolic alkalosis which has not been described in an adequate hypothesis is the relation of the acidity-alkalinity of the intake (largely reflected by $\mathrm{Na}: \mathrm{Cl}$ ratio) to the alkalosis. In the rat, the development of alkalosis in the face of potassium depletion is clearly accelerated by a high ratio of $\mathrm{Na}$ to $\mathrm{Cl}$ in the diet. Rats depleted of potassium on an intake of $\mathrm{NaCl}$ in a 1:1 molar ratio (8) took much longer to develop alkalosis than those on a diet with a ratio of 2:1 (2), and the potassiumdepletion alkalosis can be corrected by an increase in the acidity of the diet without potassium replacement or rubidium substitution (12). Muntwyler, Griffin, Samuelsen and Griffith (6) found that the development of alkalosis in dogs was much more closely related to the chloride intake than to the relative loss of intracellular potassium and gain of intracellular sodium. Certainly a distinct species difference in susceptibility to alkalosis between rats and dogs exists $(6,29)$, perhaps due to a tendency of rats to lose more chloride in stools during potassium depletion (31). Finally, in Subject 1 of Black and Milne (13) the extracellular alkalosis which developed during seven days of potassium depletion was possibly conditioned by the increased intake of fixed cation in relation to fixed anion in the resin-treated milk diet.

The effect of desoxycorticosterone (or like endogenous steroids) on the relative renal excretion of sodium and acid cannot be neglected in considering the pathogenesis of the alkalosis. With the administration of DCA the renal excretion of acid increased sharply above the expected level of excretion (Figure 2), the additional acid excretion being secondary to an increase in sodium reabsorption with an attendant increase in hydrogen ion secretion. Certainly in the presence of evidence of increased adrenal cortical activity very definite metabolic alkalosis may develop with modest potassium losses (32). A striking demonstration of the effect of DCA in precipitating metabolic alkalosis in the face of small potassium deficits and chloride loss was 
presented by Moore and associates (16), who suggested the importance of DCA in the blockade of renal correction of alkalosis. However, in the present study the renal effect of DCA appears to have led primarily to an absolute or relative decrease of intracellular hydrogen rather than to a marked increase in extracellular content and concentration of bicarbonate. The increases in extracellular bicarbonate concentration are apparently more closely related and proportional to the additional potassium loss induced by the DCA than to its renal acid-base effect.

The additional conclusions are, first, that an intake of sodium substantially in excess of chloride intake favors the development of an alkalosis, whereas high chloride intakes diminish the likelihood of alkalosis (1). Secondly, the exact relations between increments of intracellular acidity and cation deficits are probably not simply expressed by the difference between potassium lost and sodium gained. The chief physiological problems remaining for intensive study in this area include the reliability of the chloride space estimation as an index of extracellular fluid volume in the circumstances of potassium depletion, the exact role of chloride intake and excretion and a more exact analysis of muscle cation and anion composition.

\section{SUMMARY AND CONCLUSIONS}

Four balance studies were done on three normal male human subjects depleted of potassium by dietary deprivation of the ion for periods of 12 to 16 days. The treated milk diet contained less than $1 \mathrm{mEq}$. of potassium and up to 350 mEq. of sodium per day with a $\mathrm{Cl}: \mathrm{HCO}_{3}-$ ratio of $3: 1$. During the final five or six days of depletion, desoxycorticosterone was given in doses of $20 \mathrm{mg}$. per day.

Potassium deficits developed ranging from 288 to $618 \mathrm{mEq}$. per subject ( 221 to $502 \mathrm{mEq}$. when corrected for nitrogen balance), the rate of potassium loss in stool and in urine being accelerated by the DCA. Sodium was retained in excess of chloride. Urinary $\mathrm{pH}$ showed only small changes but the excretion of ammonium ion increased; the renal excretion of total acid was diminished relative to the excretion calculated as necessary to maintain external acid balance prior to DCA and was relatively increased during DCA admin- istration. Hypokalemia developed in all four subjects; a slight tendency to extracellular metabolic alkalosis appeared in two subjects and a substantial alkalosis occurred in a third.

Derived data showed about a 2:3 ratio for the exchange of extracellular sodium for intracellular potassium (relative to chloride space) in all subjects and roughly a 1:1 ratio for replacement by hydrogen of the cellular deficit of potassium over sodium in three of the subjects; in the fourth, intracellular retention of hydrogen was greatly in excess of this portion.

It is concluded that potassium depletion due to dietary deprivation of normal human subjects results in: 1) partial replacement by sodium of the cellular potassium deficit in the approximate ratio of $2: 3$ as found by Darrow, Schwartz, Iannucci and Coville in rats $(2) ; 2$ ) a more widely variable shift of hydrogen from the extracellular phase with resultant extracellular deficit of hydrogen or excess of bicarbonate and buffer anions; 3) a tendency for the changes in renal acid excretion to affect more the acid content of the intracellular rather than of the extracellular phase ; and 4) development of extracellular metabolic alkalosis in terms of a rise in concentration of bicarbonate and total buffer anion depending upon the associated change in extracellular volume and the net effect of the above internal ionic shifts.

\section{ACKNOWLEDGMENTS}

The authors wish to express appreciation for the helpful criticism of their colleagues at the University of Pennsylvania.

We are indebted to Mrs. Lidia Kosolapovs, Mrs. Katharine Wishnevski and Mr. James Mitchell for chemical analyses; to Miss Marilyn Rex and the nursing staff of the Metabolic Unit, and to Miss Nancy Sweeney and Miss Marian Wang for dietetic service.

\section{REFERENCES}

1. Squires, R. D., and Huth, E. J. Experimental potassium depletion in normal human subjects. I. Relation of ionic intakes to the renal conservation of potassium. J. clin. Invest. 1959, 38, 1134.

2. Darrow, D. C., Schwartz, R., Iannucci, J. F., and Coville, F. The relation of serum bicarbonate concentration to muscle composition. J. clin. Invest. 1948, 27, 198.

3. Cooke, R. E., Segar, W. E., Cheek, D. B., Coville, F. E., and Darrow, D. C. The extrarenal correction of alkalosis associated with potassium deficiency. J. clin. Invest. 1952, 31, 798. 
4. Cooke, R. E., Segar, W. E., Reed, C., Etzwiler, D. D., Vita, M., Brusilow, S., and Darrow, D. C. The role of potassium in the prevention of alkalosis. Amer. J. Med. 1954, 17, 180.

5. Conway, E. J., and Hingerty, D. Relations between potassium and sodium levels in mammalian muscle and blood plasma. Biochem. J. 1948, 42, 372.

6. Muntwyler, E., Griffin, G. E., Samuelsen, G. S., and Griffith, L. G. The relation of the electrolyte composition of plasma and skeletal muscle. J. biol. Chem. 1950, 185, 525.

7. Gardner, L. I., MacLachlan, E. A., and Berman, H. Effect of potassium deficiency on carbon dioxide, cation, and phosphate content of muscle. With note on carbon dioxide content of human muscle. J. gen. Physiol. 1952, 36, 153.

8. Carone, F. A., and Cooke, R. E. Effect of potassium deficiency on gastric secretion in the rat. Amer. J. Physiol. 1953, 172, 684.

9. Orloff, J., Kennedy, T. J., Jr., and Berliner, R. W. The effect of potassium in nephrectomized rats with hypokalemic alkalosis. J. clin. Invest. 1953, 32, 538.

10. Schwartz, R., Cohen, J., and Wallace, W. M. Tissue electrolyte changes of the whole body, muscle, erythrocyte and plasma of rats on a potassium deficient diet. Amer. J. Physiol. 1953, 172, 1.

11. Cheek, D. B., and West, C. D. Alterations in body composition with sodium loading and potassium restriction in the rat: The total body sodium, nitrogen, magnesium and calcium. J. clin. Invest. 1956, 35, 763.

12. Relman, A. S., Roy, A. M., and Schwartz, W. B. The acidifying effect of rubidium in normal and potassium-deficient alkalotic rats. $\mathrm{J}$. clin. Invest. 1955, 34, 538.

13. Black, D. A. K., and Milne, M. D. Experimental potassium depletion in man. Clin. Sci. 1952, 11, 397.

14. Womersley, R. A., and Darragh, J. H. Potassium and sodium restriction in the normal human. $\mathrm{J}$. clin. Invest. 1955, 34, 456.

15. Schwartz, W. B., and Relman, A. S. Metabolic and renal studies in chronic potassium depletion resulting from overuse of laxatives. J. clin. Invest. 1953, 32, 258.

16. Moore, F. D., Boling, E. A., Ditmore, H. B., Jr., Sicular, A., Teterick, J. E., Ellison, A. E., Hoye, S. J., and Ball, M. R. Body sodium and potassium. V. The relationship of alkalosis, potassium deficiency and surgical stress to acute hypokalemia in man. Experiments and review of the literature. Metabolism 1955, 4, 379.

17. Elkinton, J. R., and Danowski, T. S. The Body Fluids: Basic Physiology and Practical Therapeutics. Baltimore, Williams and Wilkins Co., 1955, pp. 83-101.
18. Barker, E. S., Singer, R. B., Elkinton, J. R., and Clark, J. K. The renal response in man to acute experimental respiratory alkalosis and acidosis. J. clin. Invest. 1957, 36, 515.

19. Cheek, D. B., West, C. D., and Golden, C. C. The distribution of sodium and chloride and the extracellular fluid volume in the rat. J. clin. Invest. 1957, 36, 340.

20. Eliel, L. P., Pearson, O. H., and Rawson, R. W. Postoperative potassium deficit and metabolic alkalosis. New Engl. J. Med. 1950, 243, 471.

21. Miller, A. T., Jr., and Blyth, C. S. Estimation of lean body mass and body fat from basal oxygen consumption and creatinine excretion. J. appl. Physiol. 1952, 5, 73.

22. Elkinton, J. R., Singer, R. B., Barker, E. S., and Clark, J. K. Effects in man of acute experimental respiratory alkalosis and acidosis on ionic transfers in the total body fluids. J. clin. Invest. 1955, 34, 1671.

23. Fourman, $P$. Depletion of potassium induced in man with an exchange resin. Clin. Sci. 1954, 13, 93.

24. Evans, B. M., Hughes Jones, N. C., Milne, M. D., and Steiner, S. Electrolyte excretion during experimental potassium depletion in man. Clin. Sci. $1954,13,305$.

25. Scribner, B. H., and Burnell, J. M. Interpretation of the serum potassium concentration. Metabolism 1956, 5, 468.

26. Roberts, K. E., Randall, H. T., Sanders, H. L., and Hood, M. Effects of potassium on renal tubular reabsorption of bicarbonate. J. clin. Invest. 1955 , 34, 666.

27. Anderson, H. M., and Mudge, G. H. The effect of potassium on intracellular bicarbonate in slices of kidney cortex. J. clin. Invest. 1955, 34, 1691.

28. Huth, E. J. Experimental potassium depletion in normal human subjects. III. Effects of simultaneous sodium bicarbonate loading and chloride restriction. In preparation.

29. Iacobellis, M., Muntwyler, E., and Griffin, G. E. Kidney glutaminase and carbonic anhydrase activity and tissue electrolyte composition in potassium-deficient dogs. Amer. J. Physiol. 1955, 183, 395.

30. Eckel, R. E., Pope, C. E., II, and Norris, J. E. C. Lysine as a muscle cation in potassium deficiency. Arch. Biochem. 1954, 52, 293.

31. Gardner, L. I., MacLachlan, E. A., Terry, M. L., McArthur, J. W., and Butler, A. M. Chloride diarrhea and systemic alkalosis in potassium deficiency. Fed. Proc. 1949, 8, 201.

32. Eliel, L. P., Pearson, O. H., and White, F. C. Postoperative potassium deficit and metabolic alkalosis. The pathogenic significance of operative trauma and of potassium and phosphorus deprivation. J. clin. Invest. 1952, 31, 419. 